\title{
OCCUPATIONAL HEALTH \& SAFETY IN TEXTILE INDUSTRY
}

\author{
Praveen Kumar $\mathbf{M}^{1}$, Mugundhan.K ${ }^{2}$, Visagavel.K ${ }^{3}$ \\ ${ }^{1} P G$ Scholar, Department of Mechanical Engineering, Knowledge Institute of Technology, Tamilnadu, India \\ ${ }^{2}$ Assistant Professor, Department of Mechanical Engineering, Knowledge Institute of Technology, Tamilnadu, India \\ ${ }^{3}$ Professor Department of Mechanical Engineering, Knowledge Institute of Technology, Tamilnadu, India
}

\begin{abstract}
The study of Occupational Health and Safety in Textile industry examines to promote Health and safety to the workers in India. The Hazards and risk involved in the textile industry is high compared with other industries and least importance are given to textile industries. Most of accident do not come to the legal formalities. The People are not aware of Health \& safety is due to the workers are uneducated and management not given importance due to promote OHS in Textile industry becomes a barriers in implementing OHS. The major hazards happen are physical, chemical, ergonomically \& physiologically hazards along with these some of things which can create hazards are more working hours, improper ventilation. The RPN(Risk priority number) has been find out for all the hazards in the textile industry and FEA(fault tree analysis) is done for the hazard with highest RPN no.
\end{abstract}

Keywords: occupational health safety, Hazards, risk, legal formalities, working hours, RPN.

\section{INTRODUCTION}

The study of OHS in textile industry in Tamilnadu is studied by checklist method, questionnaire method, workers interaction. There are 1371 mills in Tamilnadu with working employees of 38461 workers. The Study monitor the OHS in textile industry includes five major sectors they are

1. Ginning Industry

2. Spinning Industry

3. Weaving Industry

4. Dyeing Industry

5. Garment Industry

The hazards can be controlled by the industry with the cooperation of the management. Most of management does not aware of Health \& safety and other problems is that the working people in the textile industries are uneducated and unaware of OHS. This condition is very difficult to control the HAZARDS and promote OHS to the workers.The hazards are prioritized by the based on the RPN number. The RPN number is calculated by the multiplication of severity, probability and detect ability.

$$
\mathrm{RPN}=\text { Severity } \mathrm{x} \text { probability } \mathrm{x} \text { Delectability. }
$$

RPN is calculated for all the hazards involved which is involved in the textile industry. The maximum value of risk priority number is 1000 . The process involved in spinning indusries are mixing, blow room, carding, comber, drawing ,simplex, spinning, auto corner ,packing.

The hazards are also controlled by (1) safety Audit (2) safety survey (3) identifying Hazards (4) Risk Analysis (5) Risk estimation (6) Job safety analysis (7) safety promotion (8) emergency preparedness (9) safety sample (10) safety committee (11) safety inspection.

\section{LITERATURE REVIEW}

The hazards happening in the Textile industries are Mechanical Hazards, physical hazards, chemical hazards, Ergonomic hazards and physiological hazards. Exposure of cotton disease called Bysinosis .The Symptoms are chest tightness, breaking problem, asthma and irritation in the Respiratory track. The study tells about the accumulation of workers, improper condition of the machine, ergonomic problem faced by the worker, dust problems , poor lighting ,ventilation and unaware of personal protective equipment not given OHS in these industries. [padmini D.S et al.,2010]. Education is the fundamental right that helps the Growth of nation. The education help the workers to get knowledge about medical rights, legal and social behavior. The people are uneducated most of them do not know OHS at workplace . The Company unaware and lack of OHS some of them are training, housekeeping, accident prevention ,hospital facility ,safety signs[ Nazia Mlik et al.,2010].To control the noise level in the company premises and outside the company necessary action must be taken that noise regulation must be adopted.[ Hafiz Danish Ashraf et al .2009 ].To maintain the quality and production, the health of worker is essential . The most important Hazard in occupational is noise. To maintain the quality and production ,the health of the worker is essential [ Ahmad $\mathrm{HO}$ et al.,2001].The Main cause of noise problem in the weaving and spinning industry is due to the poor design, overload and old machinery.[ James MG et al.,2009].In industries is noise is a big problem that affects the human peace and increase the stress.[Iqbal SM et al., 2007]. The musculoskeletal disorders are caused by continuous work, lifting high weight, doing job without appropriate procedures.[ Tiwari meenaxi et al.,2012]. 


\section{AIM AND OBJECTIVES}

The main objective of the study is conducted due to the Reasons :

1. Measure work environment issues such that noise, temperature, lighting humidity.

2. To find out Hazards in the Textile and tell the accurate control measure.

3. Detect unsafe working condition in the Textile industries.

\section{METHODOLOGY}

\subsection{Ginning Industry}

The cotton in a machine which is used to separate the cotton fiber from the seeds and the cotton send to the textile for making yarn. The one of main Hazard in ginning industry is fire, the causes of fire happens in the Ginning Industry are Electrical, Manmade Behavior, spark from the Machine and stored Raw cotton in sunlight and other causes.

\subsection{Working and Living Condition of Worker}

\subsubsection{Overworked Labour Force}

All workers, whether they are willingly to work or non will to work they are forced to work for 12 hours. These 12 hours does not include overtime. some workers complaint that they are forcing to work more than that time. As per Factories act 1948 under chapter -6 working hours of Adults in section 51 ,no worker should not work more than 48 hours in a week and compensation Holiday must be given for Extra working days..

\subsubsection{Unprotected Working Condition}

As we know that inhalation of cotton fiber leads to BYSONIS. so It is compulsory to use Masks for these working Environment but no one following these safety Measure. As per factories act 1948,under chapter -4 ,under section 27 says, prohibition of employment of women and children near cotton opener.

\section{Types of Hazards}

1) Physical hazards

noise, fire, temperature.

2)Electrical hazards

short circult happens.

3) Ergonomically hazards

continuous work, improper work station.

4) Physiological hazards

personal ploblems, financial problem.

Table-1 Details of work environment of Ginning industry

\begin{tabular}{|l|l|l|}
\hline Parameters & Range & Mean \\
\hline Noise(dBA) & $88-92$ & 90 \\
\hline Lightning(lux) & $45-63$ & 54 \\
\hline Temperature(c) & $28-30$ & 29 \\
\hline Humidity(\%) & ---- & 56.41 \\
\hline
\end{tabular}

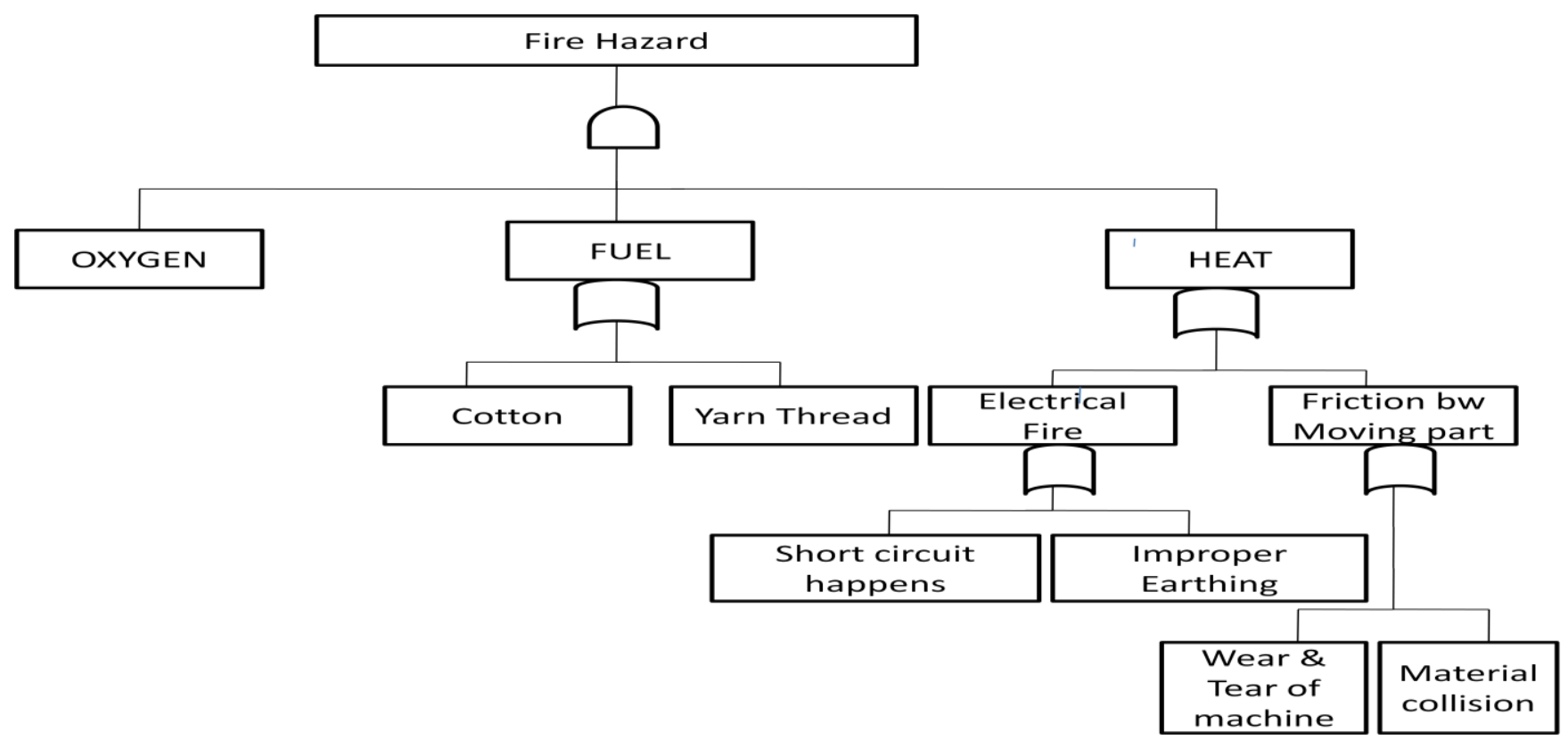

Chart-1 FEA for Fire hazard in ginning industries 
Table 2: Hazards involved in Ginning \& spinning industries

\begin{tabular}{|c|c|c|c|c|}
\hline S.NO & HAZARD & CONSEQUENCES & $\begin{array}{l}\text { ACTION REMEDIAL } \\
\text { ACTION }\end{array}$ & $\begin{array}{l}\text { RPN NO = Severity } \mathrm{x} \\
\text { detect ability } \mathrm{X} \\
\text { probability. }\end{array}$ \\
\hline 1 & $\begin{array}{l}\text { Physical hazards } \\
\text { a)Noise }\end{array}$ & $\begin{array}{l}\text { Noise induced hearing loss, } \\
\text { Tinnitus }\end{array}$ & $\begin{array}{l}\text { 1)Isolation of the } \\
\text { machine and Silencer } \\
\text { must be kept. } \\
\text { 2)Inverted drive control } \\
\text { noise in ring frame. } \\
\text { 3)proper maintenance } \\
\text { lubricating control noise }\end{array}$ & $9 \times 9 \times 8=648$ \\
\hline 2 & b)Dust & $\begin{array}{l}\text { Causes respiratory problems } \\
\text { and causes Byssinosis( a } \\
\text { disease caused by cotton } \\
\text { dust) }\end{array}$ & $\begin{array}{l}\text { 1)Dust collector 2)proper } \\
\text { House keeping and } \\
\text { 3)necessary PPE should } \\
\text { were by worker }\end{array}$ & $10 \times 10 \times 10=1000$ \\
\hline 3 & c)Light & Eye strain and glaring & $\begin{array}{l}\text { Proper lightning } \\
\text { condition }\end{array}$ & $7 \times 8 \times 7=392$ \\
\hline 4 & $\begin{array}{l}\text { d)Lifting Heavy } \\
\text { weight }\end{array}$ & $\begin{array}{l}\text { Muscular-Skeletal } \\
\text { Disorders }\end{array}$ & $\begin{array}{l}\text { 1)keep your backbone } \\
\text { straight while lifting } \\
\text { load. } \\
\text { 2)pull the load as close to } \\
\text { the body. } \\
\text { 3)Lift and carry loads } \\
\text { with straight arms }\end{array}$ & $10 \times 7 \times 9=630$ \\
\hline \multirow[t]{4}{*}{ b). } & Fire Hazards & $\begin{array}{l}\text { Loss of life, Damages to the } \\
\text { equipments. }\end{array}$ & $\begin{array}{l}\text { Fire hydrant system and } \\
\text { sprinkler system }\end{array}$ & $10 \times 10 \times 9=900$ \\
\hline & a)Welding operation & $\begin{array}{l}\text { Spark ignition is very } \\
\text { dangerous. }\end{array}$ & $\begin{array}{l}\text { Restrict unauthorized } \\
\text { person to do welding }\end{array}$ & $10 \times 9 \times 10=900$ \\
\hline & $\begin{array}{l}\text { b)Electrical short circuit } \\
\text { happens }\end{array}$ & $\begin{array}{l}\text { If no trip occurs its get } \\
\text { sparks and get fire. }\end{array}$ & $\begin{array}{l}\text { ACB (Air circuit } \\
\text { breaker),MCB } \\
\text { (motor circuit breaker). }\end{array}$ & $8 \times 8 \times 8=512$ \\
\hline & c) Smoking & Easily gets fire & $\begin{array}{l}\text { Safety signs \& workers } \\
\text { must aware of not using } \\
\text { any ignition product }\end{array}$ & $10 \times 10 \times 9=900$ \\
\hline S.NO & HAZARD & CONSEQUENCES & $\begin{array}{l}\text { ACTION REMEDIAL } \\
\text { ACTION }\end{array}$ & $\begin{array}{ll}\text { RPN NO = Severity } & \text { X } \\
\text { detectability } & \mathrm{x} \\
\text { probability. } & \end{array}$ \\
\hline $\begin{array}{l}\text { ii). } \\
\text { 1. }\end{array}$ & $\begin{array}{l}\text { Electrical hazards: } \\
\text { a)Improper Earthing }\end{array}$ & Trip occurs & $\begin{array}{l}\text { Avoid improper ear thing } \\
\text { and loose connection, }\end{array}$ & $10 \times 7 \times 9=630$ \\
\hline 2. & b)Improper isolation & Electric shock & $\begin{array}{l}\text { All circuits to be } \\
\text { enclosed in a proper } \\
\text { circuit. }\end{array}$ & $9 \times 10 \times 8=720$ \\
\hline 3. & c)Moisture & Proper wiring Proper wiring & $\begin{array}{l}\text { Moisture to kept in } \\
\text { control. }\end{array}$ & $9 \times 9 \times 7=567$ \\
\hline
\end{tabular}




\begin{tabular}{|c|c|c|c|c|}
\hline 4. & 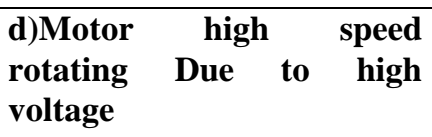 & $\begin{array}{l}\text { Causes problem to the } \\
\text { machine }\end{array}$ & $\begin{array}{l}\text { Circuit breaker must be } \\
\text { individual }\end{array}$ & $8 \times 7 \times 8=448$ \\
\hline 5. & e)Usage of old wire & Not proper current flow & $\begin{array}{l}\text { Use of wires as per } \\
\text { Electrical standard. }\end{array}$ & $7 \times 9 \times 7=441$ \\
\hline 6. & $\begin{array}{l}\text { f)Input power cable exceeds } \\
\text { More output }\end{array}$ & $\begin{array}{l}\text { Cable melting \& switch } \\
\text { becomes heat }\end{array}$ & $\begin{array}{l}\text { Input wire must be more } \\
\text { power than output wire. }\end{array}$ & $8 \times 7 \times 8=448$ \\
\hline 7. & $\begin{array}{l}\text { g)Looping in the running } \\
\text { line. }\end{array}$ & Electronics PCB & Avoid looping & $8 \times 9 \times 7=504$ \\
\hline 8. & h)Electrical Maintenance & $\begin{array}{l}\text { ECB board Check the } \\
\text { connection Grease the } \\
\text { motor frequently, }\end{array}$ & $\begin{array}{ll}\text { Needs } & \text { preventive } \\
\text { maintenance } & \end{array}$ & $8 \times 7 \times 8=448$ \\
\hline
\end{tabular}

* FTA is drawn for hazards with maximiun rpn no as shown in Chart-1and 2.

\section{Spinning industry:}

Spinning is the major part of textile industry. the textiles are fabricated into clothes. Noise is the main hazard in textile industry. The noise pollution ( Regulation and control ) rule 2000 in industrial area was $75 \mathrm{db}$ at Day Time [6 AM to 10 $\mathrm{AM}$ ] and Night time [10 PM to $6 \mathrm{AM}$ ].The fire accidents occurs in textile mills are often. The Hazards in the spinning mills are more compare to other sectors of textile industry because the Raw material cotton exposed to the fire easily. In spinning major hazard is cotton dust causes many health problems to the workers, RPN(Risk priority no) was high to this hazard.

Table -3 Ergonomically Hazards:

\begin{tabular}{|c|c|c|c|c|}
\hline 1 & $\begin{array}{l}\text { Uncomfortable work station } \\
\text { and height. }\end{array}$ & Pain in hand and legs. & Importance to ergonomics & $8 \times 8 \times 7=448$ \\
\hline 2 & Repetitive strain injuries & $\begin{array}{l}\text { Wrist, Neck, Shoulder, } \\
\text { Neck, Knee, Angle. }\end{array}$ & Proper working procedure & $8 \times 9 \times 8=576$ \\
\hline \multicolumn{5}{|c|}{ Physiological hazards: } \\
\hline 1 & Not interested to work & Physiological problem & Give counseling. & $8 \times 6 \times 6=288$ \\
\hline 2 & Production target & Stress to the worker & Set achievable Target. & $6 \times 8 \times 6=288$ \\
\hline
\end{tabular}

Table - 4 Details of working environment in spinning industries

\begin{tabular}{|l|l|l|l|}
\hline Parameters & Location of the reading & Range & Mean \\
\hline Lighting(lux) & Blow room & $78-109$ & 93.5 \\
\hline & Spinning area & $51-60$ & 55.5 \\
\hline Noise (dBA) & Spinning area & $90-95$ & 92.5 \\
\hline & Auto corner (off end \& rear end) & $86-89$ & 87.5 \\
\hline Temperature $\left({ }^{*}\right.$ c) & Preparatory unit & $24-30$ & 27 \\
\hline & Spinning room & $28-35$ & 31.5 \\
\hline Humidity $(\%)$ & Preparatory unit & ------- & 51.61 \\
\hline & Spinning room & ------- & 56.41 \\
\hline
\end{tabular}




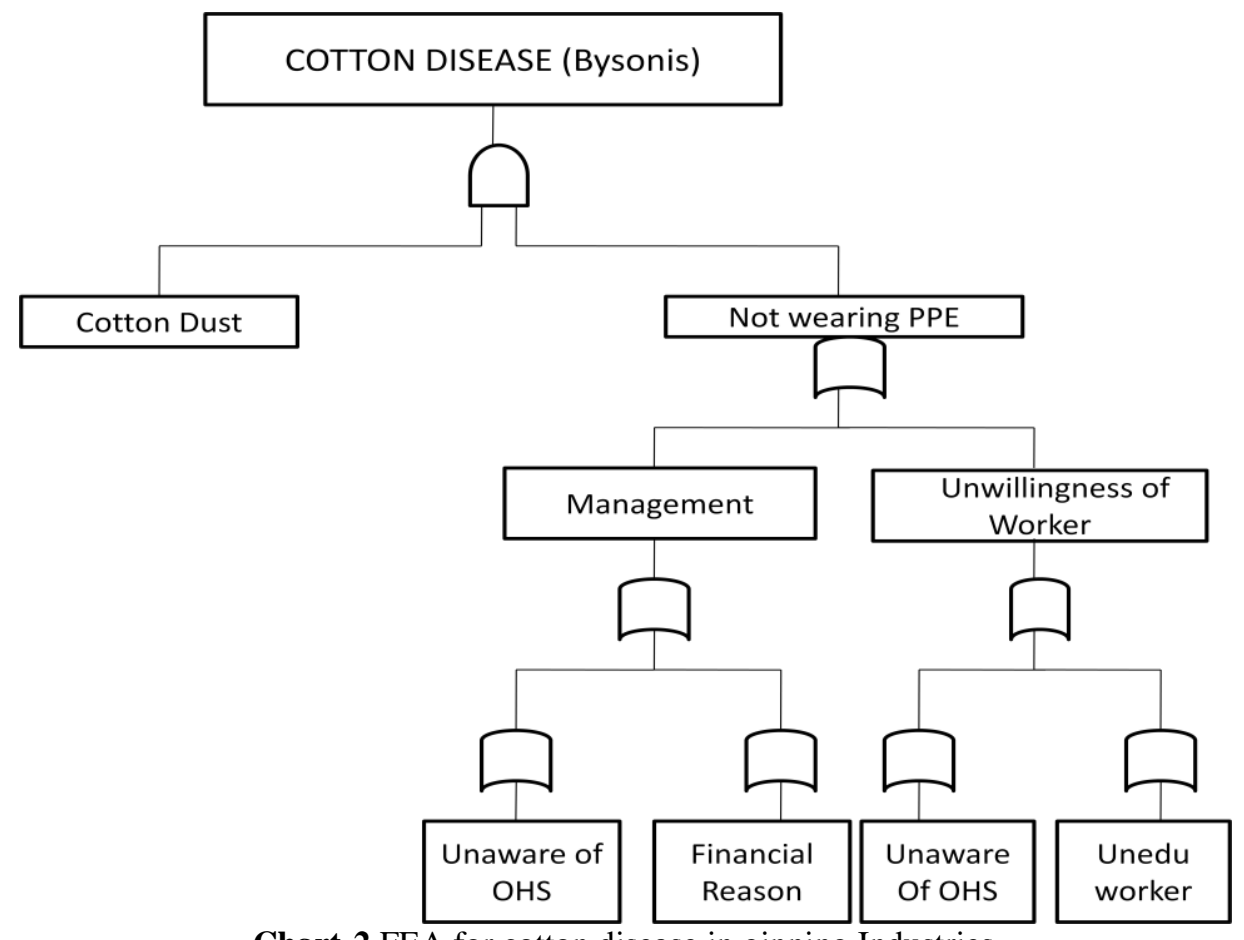

Chart-2 FEA for cotton disease in ginning Industries

\section{Dust Control}

The workroom should not be more than $0.2 \mathrm{mg} \backslash \mathrm{m}^{3}$ and controlled by some specific task. The cotton dust should be dumped with proper care and avoid storing in open container. The TWA( Time weighted average) of wool dust is $10 \mathrm{mg} \backslash \mathrm{m}^{3}$ at 8 year exposure. Excessive drying should be avoided ,if it dry the cotton dust will fly fast. The following methods to control dust is (a) proper education about cotton dust affects health.(b) proper health checkup to the affected workers (c) effective dust control method should be implement from further affecting.

\section{CONCLUSIONS}

The presented study has demonstrated the hazards and risk involved in the spinning and ginning industries. The main hazards are noise, dust, fire and electrical hazards is found by calculated RPN number, comparing to other hazards the maximum RPN is found to be harmful to the workers. so Immediate action must be taken to control these hazard to save workers health and promote safety to worker.

\section{REFERENCES}

[1]. C.W Kan..,"Occupational safety and health management system in textile industry", international lconference textile \& fashion 2012 july 3-4-12 bangok Thailand.

[2]. D.S Padmini..," Unsafe work environment in garments industries",journal of environment research and development, volume 7 no.1A 2012.

[3]. Nazia malik..," Role of hazard control measure in occupational health and safety in the textile industry of Pakistan, pak j.agri sci vol 47(1), 72-76,2010.

[4]. Hafiz Danish asraf.,"frequency of hearing loss among textile workers of wearing units in Karachi, Pakistan.
[5]. Tiwari meenaxi..," Causes of musco- skeletal disorders in textile industry", Issn 2329-3563.vol 1(4),4850,December 2012.

[6]. Vasim khatik..," The pioneer study on identification of fire hazards in cotton ginning industries of nandurbar region of Maharashtra”, volume-2,Issn 2277-8179. 